\title{
T-lymphocyte activation in steroid-sensitive nephrotic syndrome in childhood
}

\author{
T. J. Neuhaus ${ }^{1,4}$, V. Shah ${ }^{2}$, R. E. Callard ${ }^{3}$ and T. M. Barratt ${ }^{1,4}$ \\ Divisions of ${ }^{1}$ Clinical Sciences (Medical Unit), ${ }^{2}$ Biochemistry and Genetics (Biochemistry Unit) and ${ }^{3}$ Cell and Molecular \\ Biology (Cellular Immunology Unit), Institute of Child Health, London; and ${ }^{4}$ Renal Unit, Hospital for Sick Children, Great \\ Ormond Street, London, UK.
}

\begin{abstract}
We undertook a sequential study in 29 children with steroid-sensitive nephrotic syndrome (SSNS) off treatment to seek evidence for T-cell activation in relapse. T-cell subsets and activation markers were analysed using two-colour flow cytometry. Soluble IL2 receptor (sIL2R) was measured in serum and urine by enzyme-linked immunosorbent assay (ELISA). Fifteen children were examined in remission and subsequent relapse (group A) and fourteen remained in remission (group B). In group A the proportion of $\mathrm{CD}^{+}$cells expressing the activation marker CD25 (alpha-chain of the IL2 receptor) increased significantly from remission to relapse: $\mathrm{CD}^{+} 25^{+}$cells rose from 5.6 to $7.0 \%$ of total lymphocytes, and from 15.8 to $19.1 \%$ of $\mathrm{CD}^{+}$ lymphocytes (paired $t$ test: $P<0.0005$ and $<0.001$ respectively). No correlations were found between $\mathrm{CD}^{+} 25^{+}$cells and plasma albumin or cholesterol concentrations. SIL2R concentration in serum did not change in relapse, but increased significantly in urine from 272 to $592 \mathrm{U} / \mathrm{mg}$ creatinine $(P<0.01)$. No significant difference was found in remission between groups $\mathrm{A}$ and $\mathrm{B}$. We conclude that early relapse in SSNS is associated with activation of $\mathrm{CD} 4^{+}$(T-helper) cells which is not secondary due to the nephrotic state itself.
\end{abstract}

Key words: child; steroid-sensitive nephrotic syndrome; T-lymphocyte activation

\section{Introduction}

Steroid-sensitive nephrotic syndrome and minimalchange nephrotic syndrome (MCNS) in childhood have been associated with several in-vivo and in-vitro abnormalities of $\mathrm{T}$ lymphocytes [1], including decreased delayed hypersensitivity [2] and reduced responsiveness of lymphocytes to mitogens $[2,3]$. Relapse may be triggered by a viral upper respiratory

Correspondence and offprint requests to: Thomas $\mathrm{J}$ Neuhaus MD, University Children's Hospital, Steinwiesstr. 75, 8032 Zürich Switzerland. tract infection or an allergic event, whereas measles infection, which is known to inhibit T-cell function [4], is associated with remission [5]. The clinical response of SSNS to immunosuppressive treatment is also further evidence for an immune pathogenesis.

Monoclonal antibodies have been used to identify T-cell activation and T-cell subsets in peripheral blood in relapse in SSNS, but with inconclusive results so far. Some authors found no changes (compared to patients in remission or normal controls) in $\mathrm{CD}^{+} / \mathrm{CD}^{+}{ }^{+}$(total $\mathrm{T}$ cells), $\mathrm{CD}^{+}{ }^{+}$( $\mathrm{T}$-helper cells) and $\mathrm{CD}^{+}$(cytotoxic/suppressor $\mathrm{T}$ cells) subsets [6,7], whereas others reported a decrease in $\mathrm{CD}^{+}$and $\mathrm{CD} 4^{+}$ cells [8]. CD25 (or Tac) is the $\alpha$-chain of the IL2 receptor; it is expressed on activated T cells and associates with the beta and gamma chain to form the high affinity IL2 receptor [9]. CD25 showed a slight proportional increase in $\mathrm{CD}^{+}[10]$, but was unchanged in two other studies [7,8]. Expression of DR (MHC II) has been reported to be increased in $\mathrm{CD} 8^{+}$cells [8] and decreased in $\mathrm{CD}^{+}$and $\mathrm{CD}^{+}$cells [10]. Subsets of patients in remission off treatment did not differ significantly from controls $[6,8]$. Increased expression of CD25 has also been found on cultured and stimulated lymphocytes [11]. Elevated soluble IL2 receptor (sIL2R) has been recorded in various conditions associated with immune activation [12]. In SSNS increased levels have been shown in serum and urine $[13,14]$

However, these studies in SSNS differed in design: some included patients both on and off treatment and only two studies examined changes sequentially in relapse and remission $[10,13]$, the former showing increased $\mathrm{CD}^{+} 25^{+}$and $\mathrm{CD} 4{ }^{+} \mathrm{L}$-selectin ${ }^{+}$cells in relapse. A previous preliminary study from our unit, analysing different patients in different stages of SSNS, on and off treatment, had shown a slight increase in $\mathrm{CD}^{+} 25^{+}$lymphocytes and serum sIL2R in relapse [15]. Lymphocyte subsets vary considerably between individuals and are age-related [16]. Immunosuppressive treatment also affects the expression of the surface markers and the composition of lymphocyte subsets $[17,18]$. 
We therefore designed a prospective trial to follow individual patients with SSNS off treatment sequentially in remission and in early relapse. The primary hypothesis to be tested was that $\mathrm{CD}^{+}$cells were activated in relapse, compared to remission, expressing CD25. Secondly we analysed other lymphocyte activation markers and subsets.

\section{Subjects and methods}

Patients. SSNS was defined according to the International Study for Kidney Disease in Childhood [19]. Children with a stable remission ( $>6$ months) were considered for entry into the study. They were on maintenance treatment (cyclosporin A, levamisole or alternate-day steroids), which was due to be stopped to assess the tendency to relapse. Criteria for admission were: (1) normal plasma creatinine, (2) minimal-change histology (MCNS) if biopsy had been performed, (3) off cyclosporin A, levamisole and steroids for $>2$ weeks, (4) off cyclophosphamide for $>6$ months, and (5) no overt infection at time of investigation. Between November 1992 and January 1994, 260 patients with SSNS attended the Nephrotic Clinic. From this group, 29 children were eligible for the study. None of this group had been included in the previous study [15]. Informed consent was obtained. The patients were seen at intervals of 1-2 weeks, on five occasions, unless they relapsed earlier. If a relapse occurred ( 2 days $\geqslant 2+$ proteinuria on dipstick testing and urine albumin/creatinine ratio $>1.0 \mathrm{mg} / \mathrm{mg}$; normal $<0.1$ ), the child was investigated within the next $48 \mathrm{~h}$ (i.e. on day 3 or 4 after onset of proteinuria) to disentangle primary effects from possibly secondary effects related to the nephrotic state itself. Subsequently, standard relapse treatment with prednisolone was commenced. The study protocol was approved by the Ethical Committee of our hospital.

Surface phenotyping of peripheral blood lymphocytes using monoclonal antibodies. Peripheral blood was collected in the morning in heparinized tubes and analysed within $4 \mathrm{~h}$. The following lymphocyte subsets were analysed: $\mathrm{CD} 19^{+}$(B cells), $\mathrm{CD}^{+}$(total T cells), $\mathrm{CD} 4^{+}$(T-helper cells) and $\mathrm{CD} 8^{+}$ (cytotoxic/suppressor $\mathrm{T}$ cells). On all T-cell subsets the following markers were measured: CD25, DR and CD54 (ICAM-1: intercellular adhesion molecule 1) which are expressed on activated cells [20]; L-selectin (LAM-1: leukocyte adhesion molecule 1) reported to be decreased during activation [21]; CD45RA (naive $T$ cells) and CD45RO (memory T cells) [20]. All antibodies except CD45RO (Serotec, Oxford, UK) and CD54 (Dako, Bucks, UK) were purchased from Becton-Dickinson (BD), Oxford, UK. Monoclonal antibodies labelled with either fluorescein isothiocyanate (FITC) or phycoerythrin (PE) were added to the heparinized whole blood. The cells were incubated with antibody for $10 \mathrm{~min}$ at room temperature, then the red blood cells were lysed with FACS Lysing Solution (BD). The cells were washed twice and analysed immediately using a FACScan flow cytometer. The lymphocyte population was gated using forward and $90^{\circ}$ angle light scatter. Cells staining positive for FITC, PE or both were expressed as percentages using FACScan Lysis II analysis program (BD).

Serum and urine soluble interleukin 2 receptor $(s I L 2 R)$. SIL2R was measured using an ELISA test kit (Cellfree, T Cell Diagnostics, MA, USA). In addition sIL2R was analysed in 11 age-matched healthy controls attending the Dental Clinic at our Hospital. The samples were stored at $-70^{\circ} \mathrm{C}$ until required. The assay was performed according to the kit manufacturer's instructions. In brief, a murine monoclonal antibody to human IL2R was precoated onto polystyrene microtitre wells. Standards and samples were added to the wells followed by addition of a horseradish-peroxidase conjugated anti IL2R monoclonal antibody binding to a second epitope. Unbound components were removed by washing. O-phenylenediamine was added to the wells, the reaction was terminated by addition of sulphuric acid and absorbance read at $490 \mathrm{~nm}$. A standard curve was prepared from the IL2R standards and unknown values determined from the standard curve. The sensitivity of the assay was $24 \mathrm{U} / \mathrm{ml}$. Cholesterol and triglyceride concentrations (Kodak Ektachem) were also measured.

Statistical methods. A paired $t$ test was performed to determine the significance of difference between the mean of results in remission and the result in relapse; the results were expressed as mean difference and $95 \%$ confidence interval. An unpaired $t$ test was used to analyse the difference in the SIL2R data between patients and controls; the results were expressed as mean $\pm \mathrm{SD}$.

\section{Results}

Fifteen patients relapsed during the study with a mean urine albumin/creatinine ratio of $7.9 \mathrm{mg} / \mathrm{mg}$. Their median age was 11.5 years (range 6.6-17.0); 12 were males and three females. At study entry they had been off treatment for a median period of 2 weeks (range 2-48) and had a median of 3 (range 1-5) investigations during remission. The last treatment had consisted of cyclosporin A (8 children), steroids (5), and levamisole (2).

Lymphocyte subsets. There was no difference between remission and relapse in $\mathrm{CD}^{+}$cells $(68 \%$ versus 67.9$)$, $\mathrm{CD}^{+}(35.8 \%$ versus 37.1$), \mathrm{CD}^{+}(35.1 \%$ versus 34.4$)$ and $\mathrm{CD} 19^{+}(17.3 \%$ versus 17.7$)$. However, there was a highly significant increase in the proportion of $\mathrm{CD}^{+}$ cells expressing CD25 in relapse (Table 1a; Figures 1a and $1 \mathrm{~b}$ ). To test whether CD25 expression was gradually increased in remission prior to relapse, we also compared the last investigation in remission with relapse (median interval 2 weeks): There was also a significant increase (Table $1 \mathrm{~b}$ ). The sequential data of eight patients (all had at least three investigations in remission) are shown in Figures $2 \mathrm{a}$ and $2 \mathrm{~b}$. Comparing the first with the last investigation in remission (median interval 4 weeks), there was even a decrease: $\% \mathrm{CD} 4{ }^{+} 25^{+} 6.4$ versus 5.4 , and $\% \mathrm{CD} 25^{+}$per $\mathrm{CD} 4{ }^{+}$ 18.4 versus 14.0 . However, there was again a significant increase in relapse: $\% C D 4^{+} 25^{+} 6.9$, and $\% \mathrm{CD} 25^{+}$per $\mathrm{CD}^{+} 18.9(P<0.02$ and $<0.005$ respectively).

In addition to CD25 we examined a range of other T-cell markers. The subsets $\mathrm{CD}^{+} 25^{+}(5.8$ versus 7.3$)$, $\mathrm{CD}^{+} \mathrm{DR}^{+}\left(4.6\right.$ versus 5.5), $\mathrm{CD}^{+} \mathrm{LAM}^{+}(36.7$ versus 44.6$), \mathrm{CD}^{+}{ }^{+} \mathrm{LAM} 1+(20.8$ versus 25.5$)$ and $\mathrm{CD}^{+}{ }^{+} \mathrm{DR}^{+}(2.8$ versus 3.5$)$ showed a small but statistically significant $(P<0.05)$ increase in relapse. All other subsets did not differ between remission and relapse (data not shown).

Soluble IL2 receptor. There was no difference in serum between remission and relapse $(713 \pm 505 \mathrm{U} / \mathrm{ml}$ versus $710 \pm 409 \mathrm{U} / \mathrm{ml}$ ). However, there was a signific- 
Table 1a. Expression of $\mathrm{CD}^{+} 25^{+}$in remission (mean of all investigations) and relapse $(n=15)$

\begin{tabular}{lcllll}
\hline $\begin{array}{l}\mathrm{CD} \\
\text { marker }\end{array}$ & $\begin{array}{l}\text { Mean of } \\
\text { remission }\end{array}$ & $\begin{array}{l}\text { Mean of } \\
\text { relapse }\end{array}$ & $\begin{array}{l}\text { Mean } \\
\text { difference }\end{array}$ & $\begin{array}{l}95 \% \text { Confidence } \\
\text { interval }\end{array}$ & $P$ \\
\hline$\% 4^{+} 25^{+}$ & 5.6 & 7.0 & 1.4 & $0.8-1.9$ & $<0.0005$ \\
$\% 25^{+}$per $4^{+}$ & 15.8 & 19.1 & 3.3 & $1.6-5.1$ & $<0.001$ \\
$4^{+} 25^{+}\left(10^{9} / 1\right)$ & 0.140 & 0.167 & 0.027 & $0.001-0.053$ & $<0.05$ \\
\hline
\end{tabular}

$\left(\% 4^{+} 25^{+}: \%\right.$ of total lymphocytes; $\% 25^{+}$per $4^{+} ; \% 25^{+}$of total $\left.\mathrm{CD} 4^{+}\right)$.

Table 1b. Expression of $\mathrm{CD}^{+} 25^{+}$in remission (last investigation) and relapse $(n=15)$

\begin{tabular}{lcclll}
\hline $\begin{array}{l}\mathrm{CD} \\
\text { marker }\end{array}$ & $\begin{array}{l}\text { Mean of } \\
\text { remission }\end{array}$ & $\begin{array}{l}\text { Mean of } \\
\text { relapse }\end{array}$ & $\begin{array}{l}\text { Mean } \\
\text { difference }\end{array}$ & $\begin{array}{l}95 \% \text { Confidence } \\
\text { interval }\end{array}$ & $P$ \\
\hline$\% 4^{+} 25^{+}$ & 5.5 & 7.0 & 1.5 & $0.8-2.2$ & $<0.0005$ \\
$\% 25^{+}$per $4^{+}$ & 14.9 & 19.1 & 4.2 & $2.0-6.4$ & $<0.001$ \\
$4^{+} 25^{+}\left(10^{9} / 1\right)$ & 0.130 & 0.167 & 0.037 & $0.001-0.073$ & $<0.05$ \\
\hline
\end{tabular}
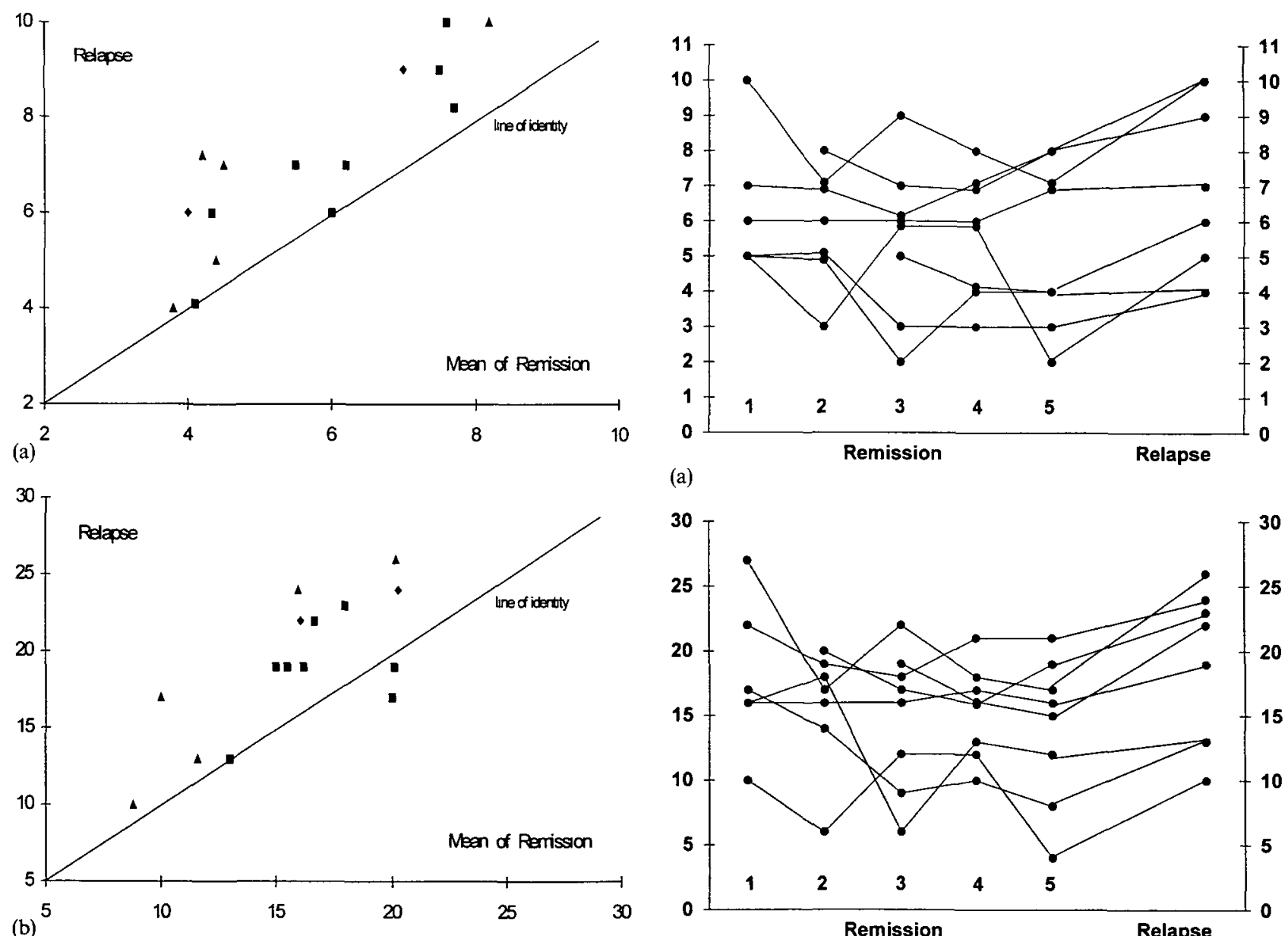

Fig. 1a. Percentage of $\mathrm{CD}^{+} 25^{+}$lymphocytes. Mean of remission versus relapse. Last treatment: cyclosporin A $\square(n=8)$, steroids $\Delta$ $(n=5)$, levamisole $\bullet(n=2)$.

(a)

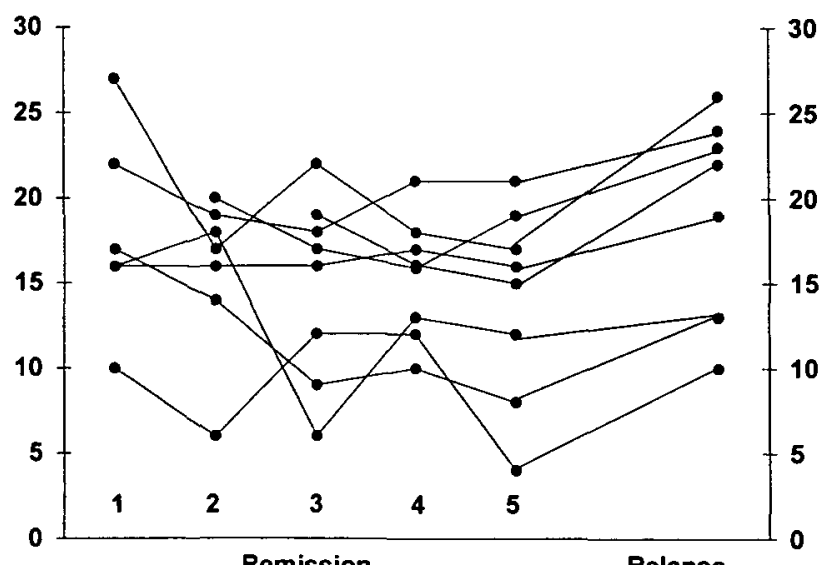

(b)

Fig. 2a. Percentage of $\mathrm{CD} 4^{+} 25^{+}$lymphocytes. Sequential data in remission (3-5 investigations) and relapse $(n=8)$.

Fig. 1b. Percentage of $\mathrm{CD}_{2} 5^{+}$per $\mathrm{CD}^{+}$lymphocytes. Mean of remission versus relapse. (symbols, see Figure la).

Fig. 2b. Percentage of $\mathrm{CD} 25^{+}$per $\mathrm{CD} 4^{+}$lymphocytes. Sequential data in remission and relapse. 
Table 2. Soluble IL2 receptor (sIL2R) in urine $(n=15)$

\begin{tabular}{lccccc}
\hline Marker & $\begin{array}{l}\text { Mean of } \\
\text { remission }\end{array}$ & $\begin{array}{l}\text { Mean of } \\
\text { relapse }\end{array}$ & $\begin{array}{l}\text { Mean } \\
\text { difference }\end{array}$ & $\begin{array}{l}95 \% \text { Confidence } \\
\text { interval }\end{array}$ & $P$ \\
\hline $\begin{array}{c}\text { sIL2R U/mg } \\
\text { creatinine }\end{array}$ & $272( \pm 308)$ & $592( \pm 440)$ & 320 & $91-549$ & $<0.01$ \\
$\begin{array}{l}\text { sIL2R fract } \\
\text { clearance }\left(\times 10^{3}\right)\end{array}$ & 1.83 & 5.22 & 3.39 & $0.58-6.20$ & $<0.05$ \\
\hline
\end{tabular}

(SD in parentheses). ${ }^{a}$ Fractional clearance: [urine sIL2R $(\mathrm{U} / \mathrm{ml}) \times$ plasma creatinine $\left.(\mathrm{mg} / \mathrm{ml})\right]:[$ serum sIL2R $(\mathrm{U} / \mathrm{ml}) \times$ urine creatinine $(\mathrm{mg} / \mathrm{ml})]$.

ant increase in the urinary excretion (Table 2). There was a positive correlation between the fractional clearance of $\operatorname{sIL} 2 \mathrm{R}$ and albumin $(\mathrm{r}=0.56, P<0.05)$, but no correlation between serum or urine sIL2R and $\mathrm{CD} 4^{+} 25^{+}$cells. Serum and urine concentrations of sIL2R did not differ between patients in remission and controls (serum: $724 \pm 215 \mathrm{U} / \mathrm{ml}$, urine: $360 \pm 372 \mathrm{U} / \mathrm{mg}$ creatinine).

Plasma lipids and albumin. These were also measured as the changes in $\mathrm{CD} 4^{+} 25^{+}$might be secondary due to the nephrotic state itself. Mean cholesterol concentration (mmol/1) rose from 4.55 (normal range 3.1-5.4) to 6.86 in relapse $(P<0.05)$, triglycerides were unchanged and mean albumin $(\mathrm{g} / \mathrm{l})$ dropped from 42 to $31 \quad(P<0.005)$, though with only three patients in the 'nephrotic range' of $<25 \mathrm{~g} / \mathrm{l}$. There were no correlations between cholesterol or albumin and $\mathrm{CD}^{+} 25^{+}$T cells.

Patients in sustained remission. Fourteen patients remained in remission during the study and had five investigations. There were no significant differences in the lymphocyte results for this group compared with the patients who subsequently relapsed: $\mathrm{CD}^{+} 72.6 \%$, $\mathrm{CD} 4{ }^{+} 39 \%, \mathrm{CD} 8^{+} 34 \%, \mathrm{CD} 4^{+} 25^{+} 5.4 \%$, and $\mathrm{CD} 25^{+}$ per $\mathrm{CD}^{+} 14.2 \%$. The sequential data for $\% \mathrm{CD}^{+} 25^{+}$are shown in Figure 3 (mean of first and last investigation: 5.6 and $5.4 \%$ respectively). The treatment before study entry differed only in cyclosporin A ( $1 / 14$ patients versus $8 / 15$ of 'relapsers'; $P<0.05$, Fisher's exact test), but not in steroids, levamisole, or cyclophosphamide $(4,7$, and 2 patients, respectively).

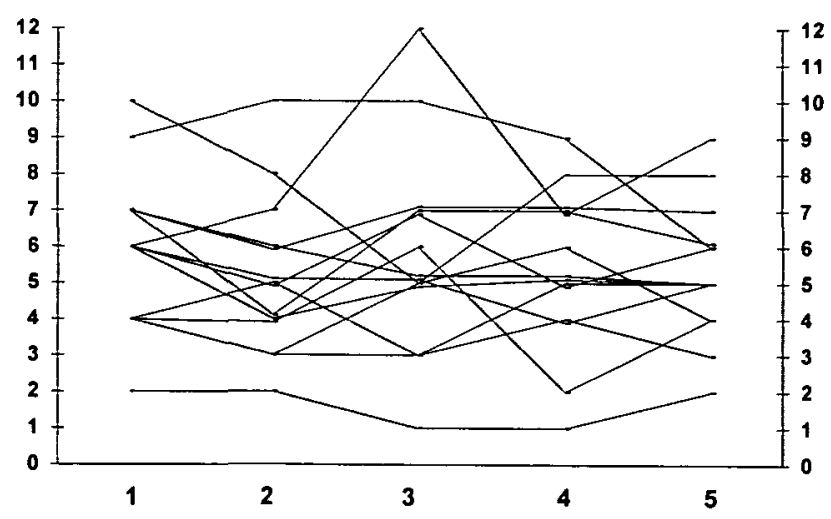

Fig. 3. Percentage of $\mathrm{CD} 4^{+} 25^{+}$lymphocytes. Sequential data in patients $(n=14)$ with sustained remission (five investigations).

\section{Discussion}

We performed a longitudinal study in SSNS to analyse T-cell activation. The proportion of $\mathrm{CD}^{+}$cells expressing the activation marker CD25 was increased in early relapse compared both with the mean of sequential investigations and with the last observation in remission, immediately prior to relapse. These findings indicate $\mathrm{T}$-helper cell activation. The absolute changes were not large, but-by performing a paired, sequential study - the results were highly significant. The absolute lymphocyte count is often unreliable, and T-cell subset data is best expressed in percentages [22].

In remission, variability between patients was consistently greater than within patients. Therefore significant changes might be missed if different patients are analysed in remission and relapse. Immunosuppressive treatment reduces the number of circulating $T$ lymphocytes, with $\mathrm{T}$ cells more affected than $\mathrm{B}$ cells; in vivo studies with single-dose corticosteroids showed a transient effect lasting less than $24 \mathrm{~h}$ [18]. All patients had been on long-term immunosuppression, but had been off treatment for at least 2 weeks when investigated. No significant adaptive changes in subsets (in particular no increase in the expression of CD25) were observed during the sequential analysis in remission, which took on average 4 weeks, suggesting that there was no longer-lasting effect of the immunosuppression. Yet we cannot rule out an increase immediately before relapse as the last investigation in remission was (on average) 2 weeks before relapse.

Are these statistical changes of clinical significance? In SSNS, remission is induced and maintained by immunosuppressive treatment. Steroids and cyclosporin $A$ inhibit the IL2/IL2R activation pathway $[17,23]$. Injection of supernatant from stimulated $T$ lymphocytes [24] or $T$ lymphocyte hybridomas [25] from patients in relapse into rats induces transient proteinuria and loss of the glomerular polyanion. These clinical and experimental observations are consistent with our findings and suggest that activated T lymphocytes are involved in the pathogenesis of SSNS.

This is the first study showing longitudinal data for sIL2R in remission and subsequent relapse, both in serum and urine. In contrast to previous studies, including one from our unit, we could not confirm increased serum concentrations of sIL2R [13,15]. All our patients were in early relapse and highly nephrotic, 
demonstrating a significant urinary loss of sIL2R. This makes the interpretation of serum SIL2R inconclusive. Urinary sIL2R excretion was positively correlated with albumin excretion. SIL2R is smaller than albumin (molecular weight $35-46 \mathrm{kDa}$ versus 66 ), but has almost the same pI (5.05 versus 4.9) [14]. Although the tubular handling of sIL2R is unknown, the urinary loss could be due to enhanced glomerular filtration. No correlation was found between serum sIL2R concentration and the proportion of activated $\mathrm{T}$ helper cells $\left(\mathrm{CD}^{+} 25^{+}\right)$.

It has been suggested that some of the T cell alterations in SSNS are epiphenomena of the nephrotic state. Lipoproteins possess immunomodulatory properties in vitro: At lower concentrations they induce T-cell activation with increased CD25 and DR expression [26], at higher concentrations they suppress mitogenesis [27]. The latter may explain (at least in part) the decreased blastogenic response in SSNS [2,3]. In relapse the plasma cholesterol was significantly raised, but only three patients had a plasma albumin in the nephrotic range; there were no correlations between albumin or cholesterol and $\mathrm{CD}_{4}{ }^{+} 25^{+}$cells. It is therefore unlikely that the $T$-cell activation is caused by changes in albumin or lipids.

$\mathrm{CD}^{+}, \mathrm{CD}^{+}{ }^{+}$and $\mathrm{CD}^{+}$subsets were similar in remission and relapse and were within the range of age-related controls [16]. The observed increases in $\mathrm{CD}^{+} 25^{+}, \mathrm{CD}^{+}{ }^{+} \mathrm{DR}^{+}$, and $\mathrm{CD} 8^{+} \mathrm{DR}^{+}$cells in relapse are consistent with $T$ cell activation, but these data need further confirmation. We analysed 22 lymphocyte subsets; this implies, apart from the primary hypothesis, a 0.68 probability $\left(1-0.95^{22}\right)$ of getting at least one spuriously significant result at the $5 \%$ level. In contrast to previous in-vitro data [21], but consistent with clinical data in SSNS [10], we found a rise in $\mathrm{CD}^{+}{ }^{+} \mathrm{LAM}_{1}{ }^{+}$and $\mathrm{CD} 4{ }^{+} \mathrm{LAM}{ }^{+}$during $\mathrm{T}$-cell activation in relapse.

We conclude that relapse of SSNS is associated with activation of $\mathrm{CD}^{+}{ }^{+}$( $\mathrm{T}$-helper) cells, expressing CD25. Our results suggest that this activation is not secondary due to the nephrotic state itself. However, the precise role of activated $\mathrm{T}$-helper cells in the pathogenesis of SSNS is still unclear.

Acknowledgements. TJN was supported by the Karl Reiser and Heinrich Paur Fund, Zurich and by the Jubiläumsstiftung Rentenanstalt, Zurich.

\section{References}

1. Schnaper HW. The immune system in minimal change nephrotic syndrome. Pediatr Nephrol 1989; 3: 101-110

2. Fodor P, Saitúa MT, Rodriguez E, González B, Schlesinger L. T-cell dysfunction in minimal-change nephrotic syndrome of childhood. Am J Dis Child 1982; 136: 713-717

3. Schulte-Wissermann H, Lemmel E-M, Reitz M, Beck J, Straub E. Nephrotic syndrome of childhood and disorder of $\mathrm{T}$ cell function. Eur J Pediatr 1977; 124: 121-128

4. Joffe MI, Rabson AR. Dissociation of lymphokine production and blastogenesis in children with measles infections. Clin Immunol Immunopathol 1978; 10: 335-343
5. Blumberg RW, Cassady HA. Effect of measles on the nephrotic syndrome. Am J Dis Child 1947; 73: 151-168

6. Herrod HG, Stapleton FB, Trouy RL, Roy S. Evaluation of T lymphocyte subpopulations in children with nephrotic syndrome. Clin Exp Immunol 1983; 52: 581-585

7. Tejani A, Suthanthiran M, Pomrantz A. A randomized controlled trial of low-dose prednisone and ciclosporin versus highdose prednisone in nephrotic syndrome of children. Nephron $1991 ; 59: 96-99$

8. Fiser RT, Arnold WC, Charlton RK, Steele RW, Childress SH, Shirkey B. T-lymphocyte subsets in nephrotic syndrome. Kidney Int 1991; 40: 913-916

9. Taniguchi T, Minami Y. The IL-2/IL-2 receptor system: a current overview. Cell 1993; 73: 5-8

10. Kobayashi K, Yoshikawa N, Nakamura H. T-cell subpopulations in childhood nephrotic syndrome. Clin Nephrol 1994; 41: $253-258$

11. Topaloglu R, Saatçı Ü, Arikan M, Canpinar H, Bakkaloglu A, Kansu E. T-cell subsets, interleukin-2 receptor expression and production of interleukin-2 in minimal change nephrotic syndrome. Pediatr Nephrol 1994; 8: 649-652

12. Rubin LA, Nelson DL. The soluble interleukin-2 receptor: Biology, function and clinical application. Ann Intern Med 1990; 113: 619-627

13. Mandreolı $M$, Beltrandi E, Casadei-Maldini $M$, Mancini $R$ Zucchelli A, Zucchell P. Lymphocyte release of soluble IL-2 receptors in patients with minimal change nephropathy. Clin Nephrol 1992; 37: 177-182

14. Bock GH, Ongkıngco JR, Patterson LT, Ruley J, Schroepfer LR, Nelson DL. Serum and urine soluble interleukin-2 receptor in idiopathic nephrotic syndrome. Pediatr Nephrol 1993; 7: $523-528$

15. Hulton SA, Shah V, Byrne MR, Morgan G, Barratt TM, Dillon MJ. Lymphocyte subsets and interleukin 2 receptor expression in childhood nephrotic syndrome. Pedatr Nephrol 1994; 8: 135-139

16. Erkeller-Yuksel FM, Deneys V, Yuksel B et al. Age-related changes in human blood lymphocyte subpopulations. $J$ Pediatr 1992; 120: 216-222

17. Boumpas DT, Anastassiou ED, Older SA, Tsokos GC, Nelson $\mathrm{DL}$, Balow JE. Dexamethasone inhibits human interleukın 2 but not interleukın 2 receptor gene expression in vitro at the level of nuclear transcription. J Clin Invest 1991; 87: 1739-1747

18. ten Berge RJM, Sauerwein RW, Yong SL, Schellekens PTA Administration of prednisolone in vivo affects the ratio of OKT4/OKT8 and the LDH-isoenzyme pattern of human T lymphocytes. Clin Immunol Immunopathol 1984; 39: 91-103

19. International Study of K1dney Disease in Children. Early identification of frequent relapsers among children with minımal change nephrotic syndrome. J Pediatr 1982; 101: 514-518

20. Akbar AN, Salmon M, Janossy G. The synergy between naive and memory $\mathrm{T}$ cells during activation. Immunol Today 1991; 12: $184-188$

21. Kanof ME, James SP. Leu-8 antigen expression is diminished during cell activation but does not correlate with effector function of activated T lymphocytes. J Immunol 1988; 140: 3701-3706

22. Fahey JL. Doing it right: Measuring T cell subsets by flow cytometry. Clin Immunol Immunopathol 1990; 55: 171-172

23. Emmel EA, Verweij CL, Durand DB, Higgins KM, Lacy E, Crabtree GR. Cyclosporin A specifically inhibits function of nuclear proteins involved in T cell activation. Science 1989, 246: $1617-1620$

24. Maruyama K, Tomizawa $S$, Shimabukuro N, Fukuda T, Johshita T, Kuroume T. Effects of supernatants derived from T lymphocyte culture in minimal change nephrotic syndrome on rat kidney capillaries. Nephron 1989; 51: 73-76

25. Koyama A, Fujisaki M, Kobayash M, Igarashi $\mathbf{M}$, Narita $\mathbf{M}$. A glomerular permeability factor produced by human $T$ cell hybridomas. Kidney Int 1991; 40: 453-460

26. Frostegård J, Wu R, Giscombe R, Holm G, Lefvert AK, Nilsson $\mathrm{J}$. Induction of T-cell activation by oxidized low density lipoprotein. Arteriosclerosis 1992; 12: 461-467

27. Traill KN, Huber LA, Wick G, Jürgens G. Lipoprotein interactions with T cells: an update. Immunol Today 1990; 11:411-417

Received for publication: 24.8 .94

Accepted in revised form: 31.3 .95 